\title{
Variation and Correlation between the Physical Properties of Dogwood Seeds
}

\author{
Zdzisław KALINIEWICZ* \\ Department of Heavy Duty Machines and Research Methodology, \\ University of Warmia and Mazury in Olsztyn, Olsztyn 10-957, Poland \\ ('Corresponding author's e-mail: zdzislaw.kaliniewicz@uwm.edu.pl) \\ Received: 25 February 2019, Revised: 24 March 2020, Accepted: 23 April 2020
}

\begin{abstract}
Information about the physical properties of berries of selected dogwood species is available in the literature, but the basic physical traits of berry seeds have not been investigated to date. In this study, the terminal velocity, thickness, width, length, angle of external friction and mass of seeds of 11 dogwood species were measured. The measured parameters were used to calculate the geometric mean diameter, aspect ratio and sphericity index of each seed. The average values of the evaluated parameters were determined in the following range: terminal velocity - from 9.95 to $13.15 \mathrm{~m} \mathrm{~s}^{-1}$, thickness - from 3.31 to $5.02 \mathrm{~mm}$, width - from 4.14 to $5.38 \mathrm{~mm}$, length - from 4.33 to $11.55 \mathrm{~mm}$, angle of external friction - from 9.97 to $29.85{ }^{\circ} \mathrm{C}$, mass - from 33.06 to $175.51 \mathrm{mg}$. The analyzed dogwood species were arranged in the following ascending order based on the geometric mean diameter of their seeds: Cornus macrophylla, Cornus alba, Cornus amonum, Cornus kousa, Cornus obliqua, Cornus controversa, Cornus walteri, Cornus sanguinea, Cornus florida, Cornus officinalis and Cornus mas. The seeds of Cornus alba, Cornus controversa, Cornus florida, Cornus kousa, Cornus macrophylla, Cornus mas and Cornus officinalis could be sorted with the use of mesh sieves with longitudinal openings, the seeds of Cornus macrophylla, Cornus sanguinea and Cornus walteri - with the use of mesh sieves with round openings, and the seeds of Cornus alba, Cornus macrophylla and Cornus obliqua - with the use of cylindrical graders.
\end{abstract}

Keywords: Seed mass, Dimensions, Terminal velocity, Relationships, Sorting

\section{Introduction}

Dogwoods (genus Cornus) belong to the family Cornaceae. Their Latin name means "horn", and it refers to the hard wood of the species [1]. Dogwood species are low-branching trees or shrubs of different size, and they are distinguished based on their flowers, berries and bark. Around 60 dogwood species have been identified around the world [2,3]. Many species are resistant to frost and short-term drought, and most dogwoods are easy to cultivate. Dogwoods thrive on moderately fertile and moist soils, but selected species, mostly large-flowered, require sunny localities that are shielded from freezing winds in winter, as well as fertile, humic and permeable soils [1].

Dogwoods are grown mainly as ornamental plants. Their seeds, berries, flowers, branches, bark and leaves are sources of food for wild animals [4]. Selected species, such as the Cornus mas, produce edible berries that deliver health benefits and are used in the production of juice, jam, yogurt, liqueur and tea [59]. Dogwood seeds contain oil abundant in unsaturated fatty acids [10-12]. Dogwood berries are drupes which turn white, red, blue or black when ripe [1,2]. Berries contain 1 or 2 seeds that have to undergo long-term stratification before they can be sown $[13,14]$.

Most published studies contain information on the physicochemical properties of berries of selected dogwood species, whereas the distribution of the physical attributes of dogwood seeds and the correlations between seed traits have not been investigated. The relevant knowledge is essential for 
http://wjst.wu.ac.th

designing and modeling seed cleaning, sorting, storage, sowing and processing. The objective of this study was to determine the range of variations in the basic physical attributes of seeds of selected dogwood species and to determine the presence of correlations between these attributes for the needs of the seed sorting process.

\section{Materials and methods}

\section{Sample preparation}

The basic physical properties of 11 dogwood species were analyzed (Figure 1): Siberian dogwood (Cornus alba L.), silky dogwood (Cornus amonum Mill.), wedding cake tree (Cornus controversa Hemsl.), flowering dogwood (Cornus florida L.), Kousa dogwood (Cornus kousa Hance), large-leaved dogwood (Cornus macrophylla Wall.), Cornelian cherry (Cornus mas L.), pale dogwood (Cornus obliqua Raf.), Japanese cornel (Cornus officinalis Torr.), common dogwood (Cornus sanguinea L.) and Walter's dogwood (Cornus walteri Raf.). Seeds were obtained from 2 producers of tree, shrub, perennial plant and herb seeds - Dendrona in Pęcice and Florpak in Końskowola.

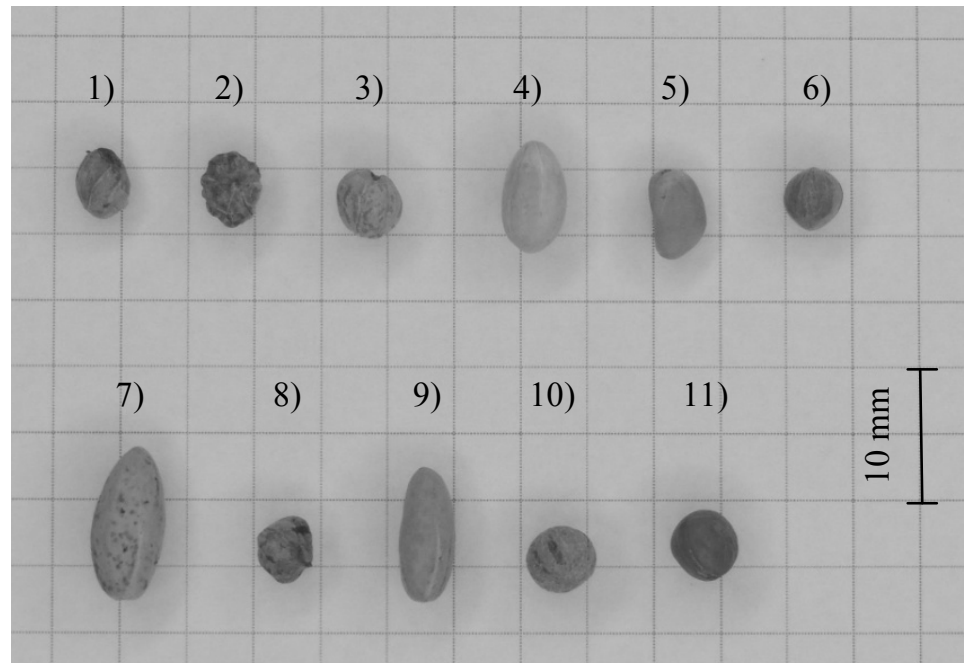

Figure 1 Seeds of: 1) Cornus alba, 2) Cornus amonum, 3) Cornus controversa, 4) Cornus florida, 5) Cornus kousa, 6) Cornus macrophylla, 7) Cornus mas, 8) Cornus obliqua, 9) Cornus officinalis, 10) Cornus sanguinea, 11) Cornus walteri.

Seed samples for analysis were obtained by cutting them into halves [15]. Every batch of seeds was halved, and 1 half was randomly selected for successive halving. The above procedure was repeated to produce samples of around 100 seeds each. The analyzed samples contained 101 to 121 seeds.

\section{Physical properties}

Terminal velocity (v) was determined in the Petkus K-293 pneumatic classifier, basic seed dimensions - under the MWM 2325 laboratory microscope (length L and width $\mathrm{W}$ ) and with a thickness (T) gauge, the angle of external friction $(\gamma)$ - on a steel friction plate (surface roughness $-\mathrm{Ra}=0.48 \mu \mathrm{m}$ ) positioned on a horizontal plane with an adjustable angle of inclination, and seed mass $(\mathrm{m})$ - on the WAA $100 / \mathrm{C} / 2$ laboratory scale. The measurements were conducted based on the method described by Kaliniewicz et al. [16] and Kaliniewicz and Poznański [17]. The angle of external friction was expressed as the mean value of 2 measurements where seeds were arranged in different positions: with the longitudinal axis parallel and perpendicular to the direction of movement on the steel friction plate. 
http://wjst.wu.ac.th

The geometric mean diameter $\mathrm{D}$, aspect ratio $\mathrm{A}_{\mathrm{r}}$ and sphericity index $\Phi$ were determined for each seed [18]:

$\mathrm{D}=(\mathrm{T} \times \mathrm{W} \times \mathrm{L})^{1 / 3}$

$A_{r}=\frac{W}{L} \times 100$

$\Phi=\frac{\mathrm{D}}{\mathrm{L}} \times 100$

\section{Statistical analysis}

The measured physical parameters of seeds were processed in Statistica PL v. 12.5 at a significance level of $\alpha=0.05$. The differences between the measured properties were determined by 1 -way analysis of variance (ANOVA). The normality of each group was verified by the Shapiro-Wilk test, and the equality of variances was assessed with Levene's test. If the null hypothesis, which postulated that the average values of a given parameter in the analyzed seed species are equal, was rejected, the significance of differences was determined and homogenous groups were identified with the use of Duncan's test. A correlation analysis was performed to determine the strength and direction of correlations between the analyzed parameters of dogwood seeds. The degrees of correlation were evaluated with the use of Pearson's correlation coefficients. The functions describing the relationships between the physical parameters of seeds were determined by regression analysis [19]. These equations were selected by testing the functions available in the Statistica package. The function which most closely resembled the cloud of measurement points and was characterized by a high coefficient of determination was selected. Only the regression equations with a minimum coefficient of determination of 0.5 were presented in the paper.

\section{Results and discussion}

\section{Experimental material}

The accuracy with which the mean values of the analyzed physical parameters are determined can be inferred from their standard error of the estimate based on the size of the sample, standard deviation of the examined parameter and Student t-values at a given significance level. The analyzed samples consisted of 101 to 121 seeds; therefore, the standard error of the estimate in the mean values of the evaluated physical properties of dogwood seeds did not exceed:

- for terminal velocity $-0.2 \mathrm{~m} \mathrm{~s}^{-1}$,

- for seed thickness and width $-0.1 \mathrm{~mm}$,

- for seed length - $0.3 \mathrm{~mm}$,

- for the angle of external friction $-1{ }^{\circ} \mathrm{C}$,

- for seed mass - $3 \mathrm{mg}$ (Cornus florida - $5 \mathrm{mg}$, Cornus mas - $10 \mathrm{mg}$ ).

The average terminal velocity (Figure 2) ranged from $9.95 \mathrm{~m} \mathrm{~s}^{-1}$ (Cornus obliqua) to $13.15 \mathrm{~m} \mathrm{~s}^{-1}$ (Cornus sanguinea). The following dogwood species formed homogeneous groups in terms of terminal velocity: Cornus alba, Cornus amonum and Cornus obliqua; Cornus controversa and Cornus kousa; Cornus florida, Cornus macrophylla and Cornus walteri.

The average seed thickness (Figure 3) ranged from $3.31 \mathrm{~mm}$ (Cornus kousa) to $5.02 \mathrm{~mm}$ (Cornus mas). Similarities in seed thickness were observed in Cornus alba, Cornus amonum, Cornus macrophylla, Cornus obliqua and Cornus officinalis, as well as in Cornus florida, Cornus sanguinea and Cornus walteri. Cornus alba and Cornus amonum were also similar in terms of seed width. The following dogwood species formed homogeneous groups in terms of seed width (Figure 4): Cornus macrophylla, Cornus officinalis and Cornus alba; Cornus kousa and Cornus amonum; Cornus controversa, Cornus 
http://wjst.wu.ac.th

florida and Cornus walteri; and Cornus florida and Cornus sanguinea. The average seed width ranged from $4.14 \mathrm{~mm}$ (Cornus officinalis) to $5.38 \mathrm{~mm}$ (Cornus mas). Cornus florida, Cornus kousa, Cornus macrophylla, Cornus mas and Cornus officinalis differed in seed length from the remaining species (Figure 5), and their seed length ranged from $4.33 \mathrm{~mm}$ (Cornus macrophylla) to $11.55 \mathrm{~mm}$ (Cornus mas).

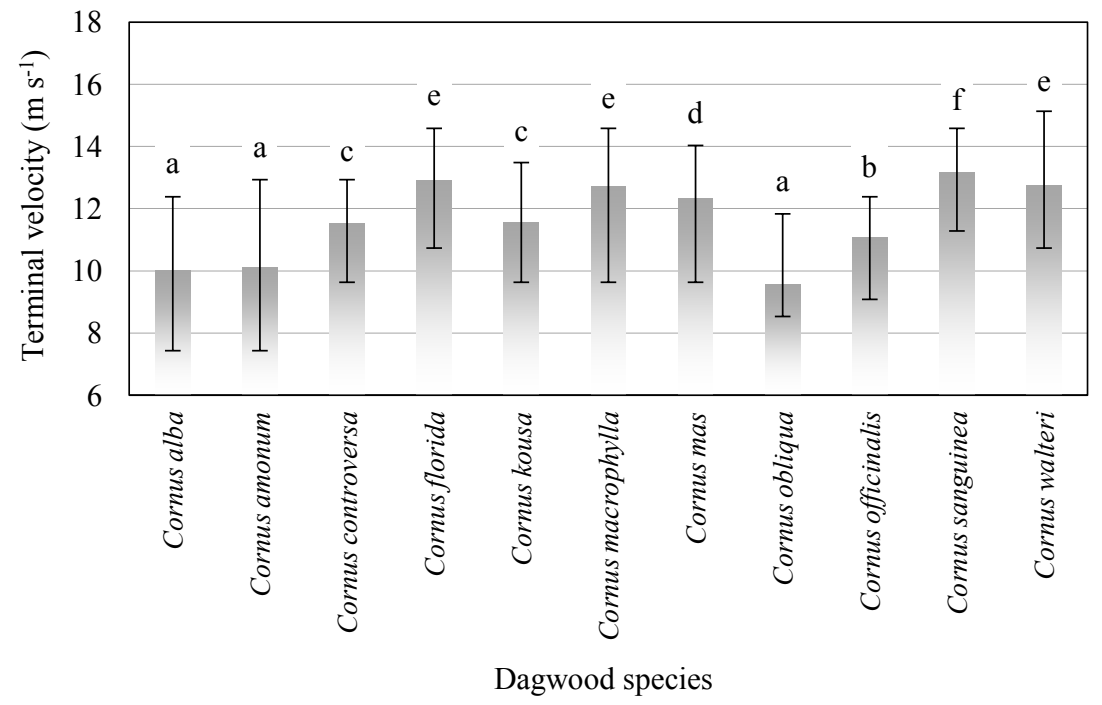

Figure 2 Terminal velocity (mean value and minimum-maximum value) of seeds and significant differences between species: a, b, c, d, e, f - various letters denote significant differences at $\mathrm{p}<0.05$ (Duncan's test).

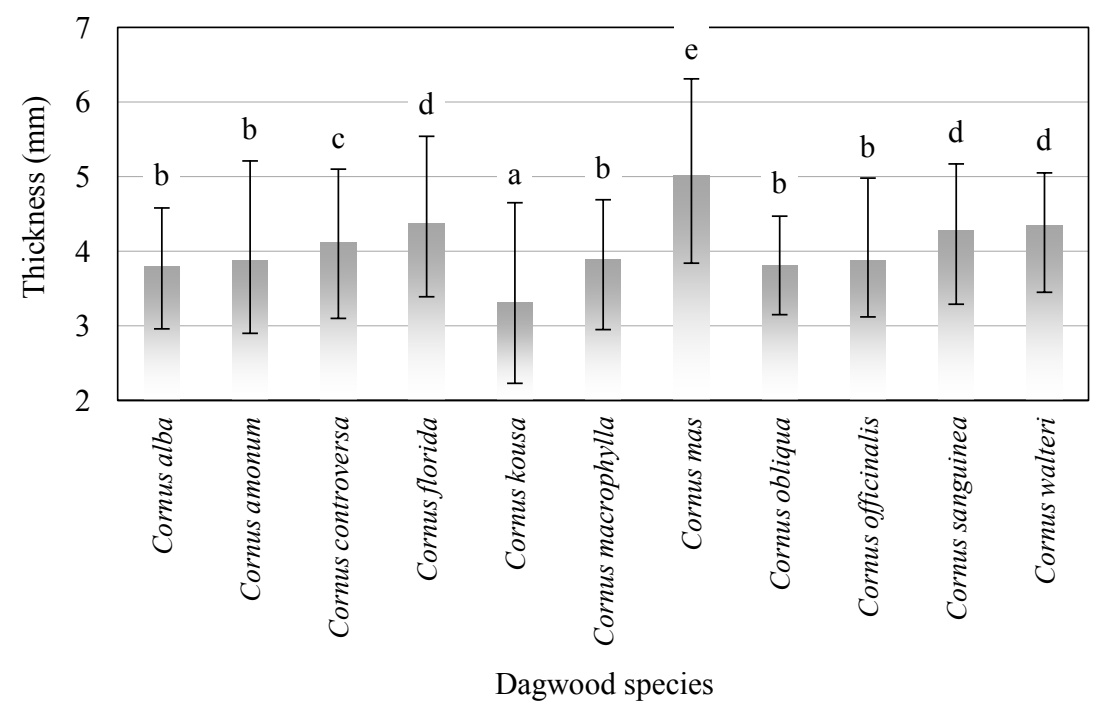

Figure 3 Thickness (mean value and minimum-maximum value) of seeds and significant differences between species: a, b, c, d, e - various letters denote significant differences at $\mathrm{p}<0.05$ (Duncan's test). 
http://wjst.wu.ac.th

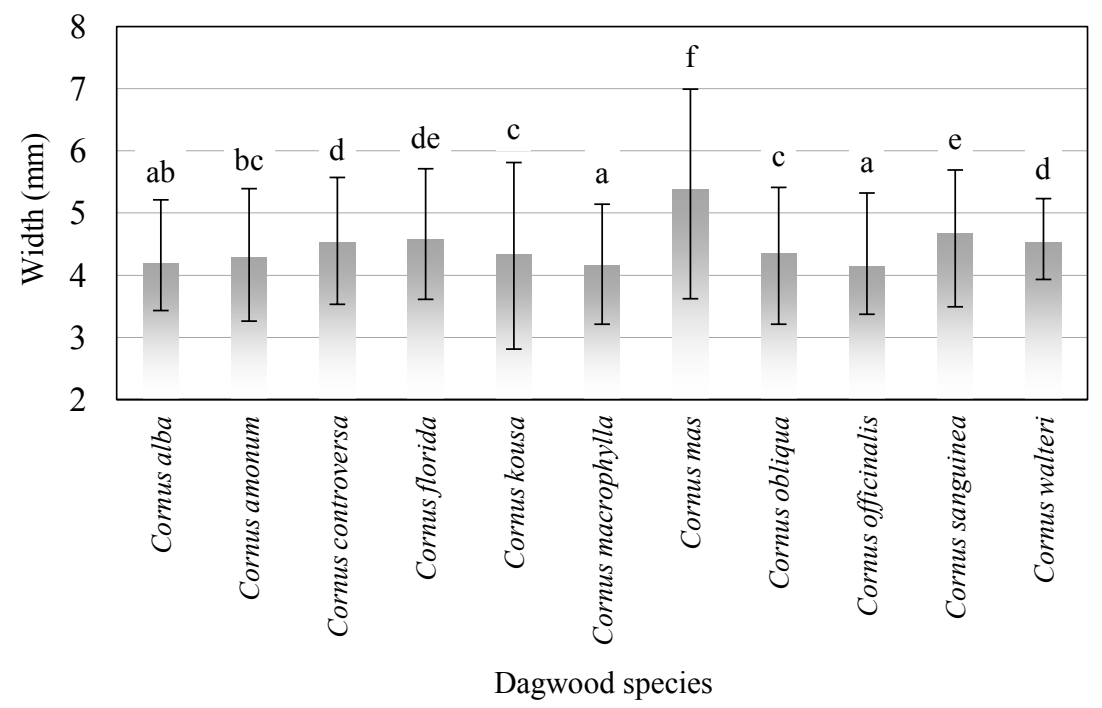

Figure 4 Width (mean value and minimum-maximum value) of seeds and significant differences between species: a, b, c, d, e, f - various letters denote significant differences at $\mathrm{p}<0.05$ (Duncan's test).

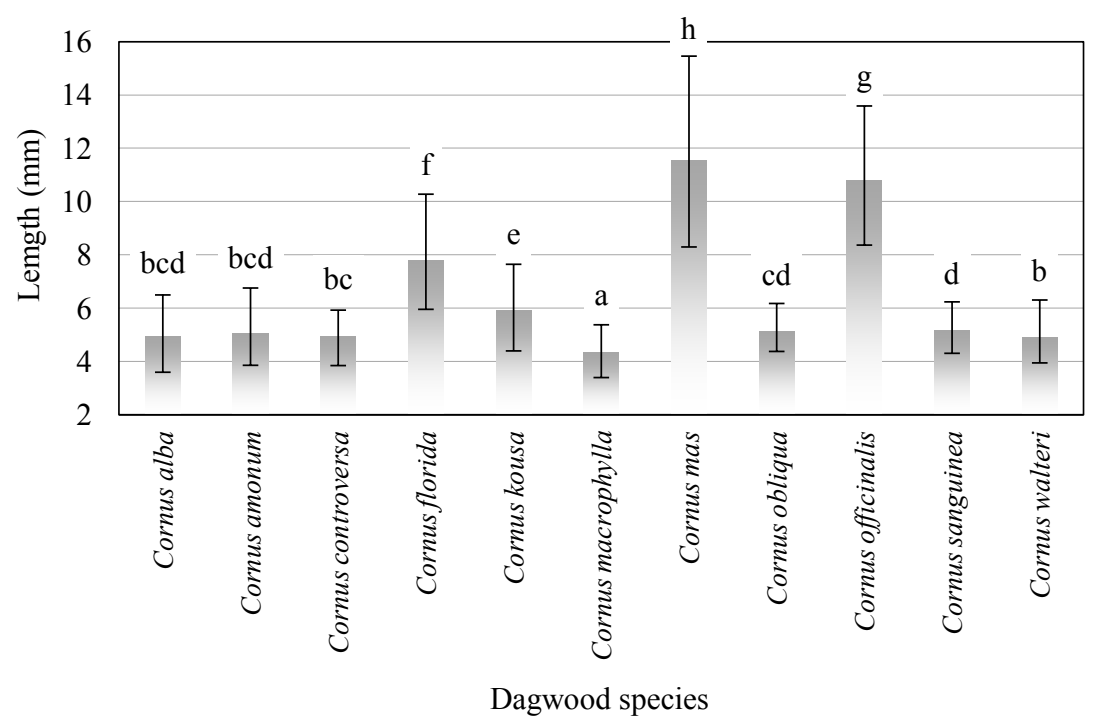

Figure 5 Length (mean value and minimum-maximum value) of seeds and significant differences between species: a, b, c, d, e, f, g, h - various letters denote significant differences at $\mathrm{p}<0.05$ (Duncan's test).

The average angle of external friction (Figure 6) ranged from $9.97{ }^{\circ} \mathrm{C}$ (Cornus macrophylla) to $29.85^{\circ} \mathrm{C}$ (Cornus alba). Cornus alba, Cornus obliqua and Cornus officinalis seeds differed from the remaining dogwood species in this parameter. 
http://wjst.wu.ac.th

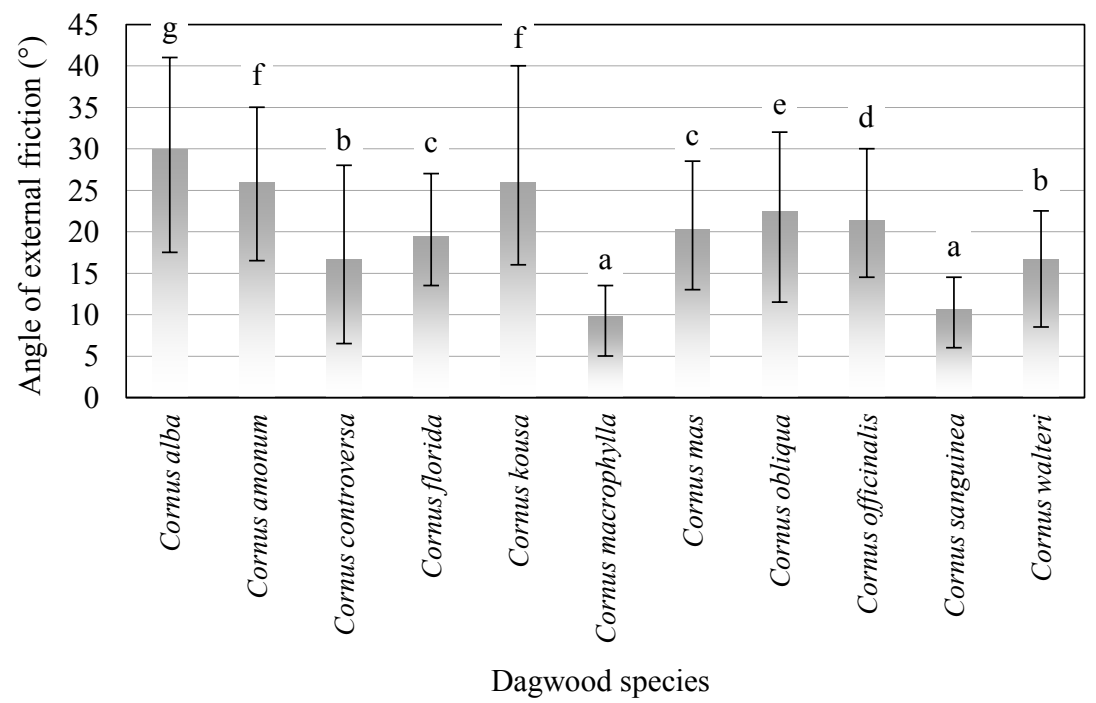

Figure 6 Angle of external friction (mean value and minimum-maximum value) of seeds and significant differences between species: $a, b, c, d, e, f, g$ - various letters denote significant differences at $p<0.05$ (Duncan's test).

The average seed mass (Figure 7) ranged from $33.06 \mathrm{mg}$ (Cornus obliqua) to $175.51 \mathrm{mg}$ (Cornus mas). The following pairs of dogwood species formed homogeneous groups in terms of average seed mass: Cornus obliqua and Cornus amonum, Cornus amonum and Cornus alba, Cornus alba and Cornus macrophylla, Cornus controversa and Cornus kousa, Cornus sanguinea and Cornus walteri, and Cornus florida and Cornus officinalis.

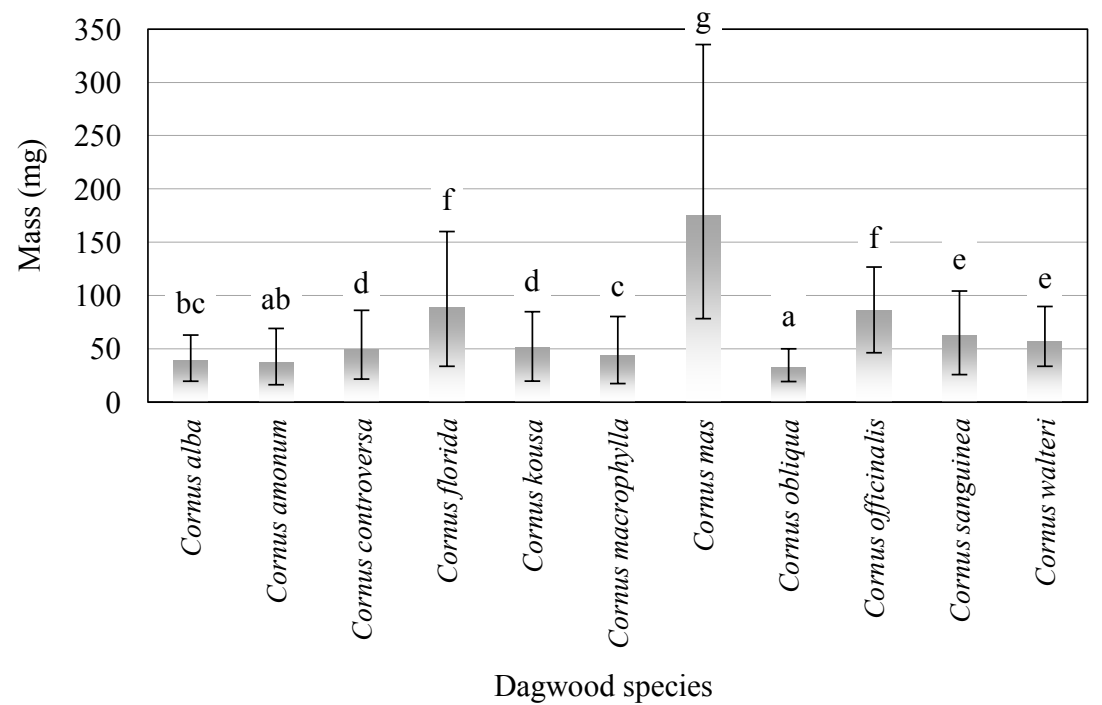

Figure 7 Mass (mean value and minimum-maximum value) of seeds and significant differences between species: a, b, c, d, e, f, g - various letters denote significant differences at $\mathrm{p}<0.05$ (Duncan's test). 
http://wjst.wu.ac.th

Based on the literature [15,20-23], the basic dimensions and mass of seeds produced by forest trees and shrubs are influenced by seed genotype, tree stand age and environmental conditions (geographic location, habitat, distribution of fruit and seeds in the crown, weather, etc.). The seeds analyzed in this study are unique in that they had been harvested only in Poland which has a temperate climate ranging from a maritime climate in the west to a continental climate in the east. An analysis of the physical parameters of seeds of the evaluated dogwood species revealed that the width of Cornus officinalis seeds was $14-42 \%$ lower than that reported by Bai et al. [24] in a study of seeds from China and the USA where growing conditions for the analyzed species are more favorable than in Poland. The width and length of Cornus mas seeds were within the range reported in Bosnia and Herzegovina [25] and Turkey [26]. The average length of Cornus officinalis seeds was around $10 \%$ higher than that reported in USgrown seeds and around $25 \%$ lower than that noted in China-grown seeds [24]. The mean mass of Cornus mas seeds was similar to that given by Demir and Kalyoncu [26], whereas the mass of Cornus officinalis seeds was 45 - $75 \%$ lower than that reported by Bai et al. [24]. The above differences were correlated with the observed variations in seed dimensions.

The indicators of the analyzed seeds are presented in Table 1. Cornus mas was characterized by the largest (geometric mean diameter of $6.78 \mathrm{~mm}$ ) and the Cornus macrophylla - by the smallest (geometric mean diameter of $4.12 \mathrm{~mm}$ ) seeds. Significant differences in the geometric mean diameter of seeds were not observed between Cornus alba, Cornus amonum, Cornus kousa and Cornus obliqua, between Cornus controversa and Cornus walteri, or between Cornus sanguinea and Cornus walteri. The following dogwood species formed homogeneous groups in terms of seed shape (aspect ratio and sphericity index): Cornus alba, Cornus amonum and Cornus obliqua, as well as Cornus controversa and Cornus sanguinea.

Table 1 Statistical distribution of the physical properties (mean value \pm standard deviation) of seeds and significant differences between species.

\begin{tabular}{|c|c|c|c|}
\hline \multirow[b]{2}{*}{ Dogwood species } & \multicolumn{3}{|c|}{ Indicator } \\
\hline & $\begin{array}{c}\text { Geometric mean } \\
\text { diameter }(\mathrm{mm})\end{array}$ & $\begin{array}{c}\text { Aspect ratio } \\
(\%)\end{array}$ & $\begin{array}{c}\text { Sphericity index } \\
(\%)\end{array}$ \\
\hline Cornus alba & $4.28 \pm 0.30^{\mathrm{b}}$ & $85.29 \pm 9.68^{\mathrm{e}}$ & $86.84 \pm 6.22^{\mathrm{e}}$ \\
\hline Cornus amonum & $4.37 \pm 0.44^{\mathrm{b}}$ & $85.37 \pm 8.36^{\mathrm{e}}$ & $86.82 \pm 5.31^{\mathrm{e}}$ \\
\hline Cornus controversa & $4.51 \pm 0.37^{\mathrm{c}}$ & $91.90 \pm 5.12^{\mathrm{fg}}$ & $91.57 \pm 3.02^{f}$ \\
\hline Cornus florida & $5.38 \pm 0.45^{\mathrm{e}}$ & $59.08 \pm 5.94^{\mathrm{c}}$ & $69.20 \pm 4.48^{c}$ \\
\hline Cornus kousa & $4.38 \pm 0.37^{\mathrm{b}}$ & $73.84 \pm 11.37^{\mathrm{d}}$ & $74.36 \pm 6.71^{\mathrm{d}}$ \\
\hline Cornus macrophylla & $4.12 \pm 0.40^{\mathrm{a}}$ & $96.28 \pm 2.90^{\mathrm{h}}$ & $95.29 \pm 2.22^{h}$ \\
\hline Cornus mas & $6.78 \pm 0.67^{\mathrm{g}}$ & $46.92 \pm 4.56^{\mathrm{b}}$ & $58.94 \pm 3.85^{\mathrm{b}}$ \\
\hline Cornus obliqua & $4.38 \pm 0.28^{b}$ & $85.20 \pm 9.24^{\mathrm{e}}$ & $85.89 \pm 5.23^{\mathrm{e}}$ \\
\hline Cornus officinalis & $5.57 \pm 0.45^{\mathrm{f}}$ & $38.57 \pm 3.93^{\mathrm{a}}$ & $51.75 \pm 3.31^{\mathrm{a}}$ \\
\hline Cornus sanguinea & $4.68 \pm 0.36^{\mathrm{d}}$ & $90.80 \pm 5.98^{f}$ & $91.01 \pm 3.68^{\mathrm{f}}$ \\
\hline Cornus walteri & $4.58 \pm 0.29^{\mathrm{cd}}$ & $92.73 \pm 5.23^{\mathrm{g}}$ & $93.80 \pm 3.82^{\mathrm{g}}$ \\
\hline
\end{tabular}

$\mathrm{a}, \mathrm{b}, \mathrm{c}, \mathrm{d}, \mathrm{e}, \mathrm{f}, \mathrm{g}, \mathrm{h}$ - various superscript letters denote significant differences at $\mathrm{p}<0.05$ (Duncan's test).

An analysis of the seeds of 11 dogwood species did not reveal any species pairs characterized by significant similarities in all of the evaluated parameters. The highest number of similarities was noted in the seeds of Cornus alba, Cornus amonum and Cornus obliqua, and in the seeds of the Cornus controversa and Cornus sanguinea, whereas Cornus mas seeds were least similar to the seeds of the remaining dogwood species. 
http://wjst.wu.ac.th

\section{Relationships between properties}

Knowledge of variations in and interactions between seed properties is required for designing and modeling seed processing operations [27]. Strong correlations between seed properties could suggest that seeds of a given species have a characteristic shape, and these proportions have to be taken into account when designing seed sorting equipment. In the current study (Table 2), the absolute value of the correlation coefficient ranged from 0.009 (angle of external friction and thickness of Cornus sanguinea seeds) to 0.951 (width and length of Cornus macrophylla seeds), and the angle of external friction was least correlated with the remaining seed properties. The linear correlation analysis of the physical parameters of seeds revealed the highest number of significant correlations between seed mass and the remaining properties of dogwood seeds (48 out of 55 comparisons). The angle of external friction was least correlated with the remaining seed properties. The correlation coefficient was practically significant (higher than 0.4 ) in only 1 case (the relationship between the angle of external friction and the terminal velocity of Cornus kousa seeds). Our findings and the results reported by Tylek [28] in a study of European beech seeds suggest that the frictional properties of seeds of forest trees and shrubs could be used as secondary rather than primary distinguishing features in seed separation processes. In 5 dogwood species (Cornus amonum, Cornus florida, Cornus mas, Cornus obliqua and Cornus officinalis), the highest values of the correlation coefficient were noted for seed thickness and seed width, and in 3 dogwood species (Cornus alba, Cornus controversa and Cornus kousa) - for seed thickness and seed mass. Seed mass and seed width were most highly correlated in Cornus sanguinea and Cornus walteri, and seed width and seed length - in Cornus macrophylla.

Table 2 Coefficients of linear correlation between the physical properties of seeds.

\begin{tabular}{|c|c|c|c|c|c|c|}
\hline \multirow{2}{*}{ Dogwood species } & & \multicolumn{5}{|c|}{ Properties } \\
\hline & & $\mathbf{v}$ & $\mathbf{T}$ & $\mathbf{W}$ & $\mathbf{L}$ & $\gamma$ \\
\hline \multirow{5}{*}{ Cornus alba } & $\mathrm{T}$ & 0.251 & 1 & & & \\
\hline & W & -0.098 & 0.599 & 1 & & \\
\hline & $\mathrm{L}$ & 0.163 & 0.292 & 0.213 & 1 & \\
\hline & $\gamma$ & -0.291 & -0.183 & 0.058 & -0.035 & 1 \\
\hline & $\mathrm{m}$ & 0.449 & 0.631 & 0.436 & 0.489 & -0.197 \\
\hline \multirow{5}{*}{ Cornus amonum } & $\mathrm{T}$ & 0.161 & 1 & & & \\
\hline & $\mathrm{W}$ & 0.117 & 0.761 & 1 & & \\
\hline & $\mathrm{L}$ & 0.230 & 0.631 & 0.580 & 1 & \\
\hline & $\gamma$ & -0.148 & -0.255 & -0.182 & 0.025 & 1 \\
\hline & $\mathrm{m}$ & 0.588 & 0.708 & 0.639 & 0.750 & -0.193 \\
\hline \multirow{5}{*}{ Cornus controversa } & $\mathrm{T}$ & 0.392 & 1 & & & \\
\hline & $\mathrm{W}$ & 0.383 & 0.783 & 1 & & \\
\hline & $\mathrm{L}$ & 0.395 & 0.778 & 0.790 & 1 & \\
\hline & $\gamma$ & -0.116 & -0.296 & 0.068 & -0.046 & 1 \\
\hline & $\mathrm{m}$ & 0.476 & 0.904 & 0.855 & 0.879 & -0.170 \\
\hline \multirow{5}{*}{ Cornus florida } & $\mathrm{T}$ & 0.468 & 1 & & & \\
\hline & $\mathrm{W}$ & 0.386 & 0.934 & 1 & & \\
\hline & $\mathrm{L}$ & 0.212 & 0.555 & 0.504 & 1 & \\
\hline & $\gamma$ & -0.214 & -0.191 & -0.147 & -0.041 & 1 \\
\hline & $\mathrm{m}$ & 0.490 & 0.875 & 0.831 & 0.806 & -0.175 \\
\hline \multirow{4}{*}{ Cornus kousa } & $\mathrm{T}$ & 0.587 & 1 & & & \\
\hline & W & 0.211 & 0.220 & 1 & & \\
\hline & $\mathrm{L}$ & 0.041 & 0.161 & 0.215 & 1 & \\
\hline & $\gamma$ & -0.454 & -0.398 & 0.143 & 0.098 & 1 \\
\hline
\end{tabular}




\begin{tabular}{|c|c|c|c|c|c|c|}
\hline \multirow{3}{*}{ Dogwood species } & & \multicolumn{5}{|c|}{ Properties } \\
\hline & & $\mathbf{v}$ & $T$ & W & $\mathbf{L}$ & $\gamma$ \\
\hline & $\mathrm{m}$ & 0.515 & 0.668 & 0.611 & 0.578 & -0.150 \\
\hline \multirow{5}{*}{$\begin{array}{c}\text { Cornus } \\
\text { macrophylla }\end{array}$} & $\mathrm{T}$ & 0.549 & 1 & & & \\
\hline & W & 0.518 & 0.839 & 1 & & \\
\hline & $\mathrm{L}$ & 0.513 & 0.848 & 0.951 & 1 & \\
\hline & $\gamma$ & -0.058 & -0.058 & 0.286 & 0.280 & 1 \\
\hline & $\mathrm{m}$ & 0.598 & 0.598 & 0.918 & 0.923 & 0.251 \\
\hline \multirow{5}{*}{ Cornus mas } & $\mathrm{T}$ & 0.425 & 1 & & & \\
\hline & W & 0.391 & 0.928 & 1 & & \\
\hline & $\mathrm{L}$ & 0.179 & 0.600 & 0.637 & 1 & \\
\hline & $\gamma$ & -0.217 & -0.344 & -0.166 & -0.187 & 1 \\
\hline & $\mathrm{m}$ & 0.455 & 0.889 & 0.822 & 0.815 & -0.285 \\
\hline \multirow{5}{*}{ Cornus obliqua } & $\mathrm{T}$ & -0.134 & 1 & & & \\
\hline & W & -0.392 & 0.578 & 1 & & \\
\hline & $\mathrm{L}$ & 0.119 & 0.279 & 0.196 & 1 & \\
\hline & $\gamma$ & -0.183 & 0.053 & 0.191 & 0.117 & 1 \\
\hline & $\mathrm{m}$ & 0.356 & 0.440 & 0.257 & 0.721 & -0.033 \\
\hline \multirow{5}{*}{ Cornus officinalis } & $\mathrm{T}$ & 0.047 & 1 & & & \\
\hline & W & 0.011 & 0.915 & 1 & & \\
\hline & $\mathrm{L}$ & 0.012 & 0.495 & 0.445 & 1 & \\
\hline & $\gamma$ & 0.009 & -0.377 & -0.276 & -0.189 & 1 \\
\hline & $\mathrm{m}$ & 0.168 & 0.839 & 0.812 & 0.781 & -0.262 \\
\hline \multirow{5}{*}{ Cornus sanguinea } & $\mathrm{T}$ & 0.439 & 1 & & & \\
\hline & W & 0.405 & 0.811 & 1 & & \\
\hline & $\mathrm{L}$ & 0.377 & 0.685 & 0.683 & 1 & \\
\hline & $\gamma$ & 0.091 & 0.009 & 0.045 & 0.201 & 1 \\
\hline & $\mathrm{m}$ & 0.499 & 0.849 & 0.892 & 0.829 & 0.058 \\
\hline \multirow{5}{*}{ Cornus walteri } & $\mathrm{T}$ & 0.436 & 1 & & & \\
\hline & W & 0.322 & 0.764 & 1 & & \\
\hline & $\mathrm{L}$ & 0.283 & 0.542 & 0.685 & 1 & \\
\hline & $\gamma$ & -0.209 & 0.064 & 0.098 & 0.046 & 1 \\
\hline & $\mathrm{m}$ & 0.448 & 0.745 & 0.829 & 0.640 & -0.019 \\
\hline
\end{tabular}

$\mathrm{v}$ - terminal velocity, $\mathrm{T}$ - thickness, $\mathrm{W}$ - width, $\mathrm{L}$ - length, $\gamma$ - angle of external friction, $\mathrm{m}$ - mass.

Values in bold indicate statistically significant correlations.

Seed mass is usually most highly correlated with other seed traits. According to many authors [2933], seed mass significantly influences germination, but heavy seeds do not always germinate faster than light seeds. In general, heavy seeds are characterized by higher germination success because they are more abundant in nutrients essential for seedling emergence. Germination uniformity and the productivity of tree nurseries could be substantially improved by dividing seed batches into fractions with similar seed mass. However, seeds are difficult to sort based on their mass, therefore, other traits correlated with seed mass should be identified.

The results of linear regression analysis (Table 3) also indicate that the angle of external friction had a minor influence on seed mass. The presence of relationships with the angle of external friction with a minimum coefficient of determination of 0.5 was not noted in any of the examined dogwood species. The equation with the highest coefficient of determination in relation to seed mass was obtained in Cornus macrophylla where seed mass was correlated with seed length (0.853). The highest value of the 
http://wjst.wu.ac.th

coefficient of determination was most frequently noted in equations describing the correlation between seed mass and seed thickness (4 out of 9 cases), which indicates that dogwood seeds can be effectively separated with the use of mesh sieves with longitudinal openings.

Table 3 Relationships between seed mass and the remaining physical properties of seeds.

\begin{tabular}{|c|c|c|c|}
\hline Dogwood species & Equation & $\begin{array}{c}\text { Coefficient of } \\
\text { determination } \mathbf{R}^{2}\end{array}$ & $\begin{array}{c}\text { Standard error } \\
\text { of estimate }\end{array}$ \\
\hline \multirow{2}{*}{ Cornus amonum } & $\mathrm{m}=16.351 \mathrm{~T}-25.719$ & 0.501 & 7.514 \\
\hline & $\mathrm{m}=13.239 \mathrm{~L}-29.324$ & 0.562 & 7.038 \\
\hline \multirow{3}{*}{ Cornus controversa } & $\mathrm{m}=27.734 \mathrm{~T}-64.731$ & 0.818 & 5.197 \\
\hline & $\mathrm{m}=25.569 \mathrm{~W}-66.092$ & 0.731 & 6.309 \\
\hline & $m=25.658 \mathrm{~L}-76.869$ & 0.772 & 5.810 \\
\hline \multirow{3}{*}{ Cornus florida } & $\mathrm{m}=51.965 \mathrm{~T}-137.970$ & 0.766 & 11.573 \\
\hline & $\mathrm{m}=50.421 \mathrm{~W}-141.922$ & 0.690 & 13.336 \\
\hline & $\mathrm{m}=22.091 \mathrm{~L}-83.577$ & 0.649 & 14.184 \\
\hline \multirow{3}{*}{ Cornus macrophylla } & $\mathrm{m}=29.874 \mathrm{~T}-72.387$ & 0.838 & 5.047 \\
\hline & $\mathrm{m}=27.400 \mathrm{~W}-70.376$ & 0.834 & 4.966 \\
\hline & $\mathrm{m}=25.132 \mathrm{~L}-65.089$ & 0.853 & 4.817 \\
\hline \multirow{3}{*}{ Cornus mas } & $\mathrm{m}=89.884 \mathrm{~T}-275.982$ & 0.790 & 24.448 \\
\hline & $\mathrm{m}=85.866 \mathrm{~W}-286.739$ & 0.778 & 25.103 \\
\hline & $\mathrm{m}=30.266 \mathrm{~L}-174.194$ & 0.664 & 30.908 \\
\hline Cornus obliqua & $\mathrm{m}=10.224 \mathrm{~L}-19.201$ & 0.520 & 3.650 \\
\hline \multirow{3}{*}{ Cornus officinalis } & $\mathrm{m}=37.082 \mathrm{~T}-57.686$ & 0.704 & 8.903 \\
\hline & $\mathrm{m}=34.172 \mathrm{~W}-55.535$ & 0.659 & 9.547 \\
\hline & $\mathrm{m}=12.387 \mathrm{~L}-47.722$ & 0.611 & 10.208 \\
\hline \multirow{3}{*}{ Cornus sanguinea } & $\mathrm{m}=33.909 \mathrm{~T}-82.373$ & 0.720 & 8.163 \\
\hline & $\mathrm{m}=33.049 \mathrm{~W}-91.652$ & 0.796 & 6.972 \\
\hline & $\mathrm{m}=32.990 \mathrm{~L}-107.145$ & 0.669 & 8.640 \\
\hline \multirow{2}{*}{ Cornus walter } & $\mathrm{m}=25.100 \mathrm{~T}-51.982$ & 0.555 & 7.233 \\
\hline & $\mathrm{m}=31.450 \mathrm{~W}-85.128$ & 0.687 & 6.071 \\
\hline
\end{tabular}

$\mathrm{T}$ - thickness, W - width, L - length, $\mathrm{m}$ - mass.

The seeds of Cornus controversa, Cornus florida, Cornus mas, Cornus officinalis as well as the seeds of Cornus alba and Cornus kousa (which are not presented in Table 3 because their coefficients of determination are lower than 0.5 ) should be sorted with the use of mesh sieves with longitudinal openings because their mass is most highly correlated with seed thickness. The seeds of Cornus sanguinea and Cornus walteri should be sorted with the use of mesh sieves with round openings (seed width as the discriminating trait), and the seeds of Cornus alba, Cornus obliqua and Cornus macrophylla - with a cylindrical grader (seed length as the discriminating trait). Cornus macrophylla seeds can also be sorted with mesh sieves with longitudinal and round openings because all 3 basic seed dimensions are similarly correlated with seed mass. 

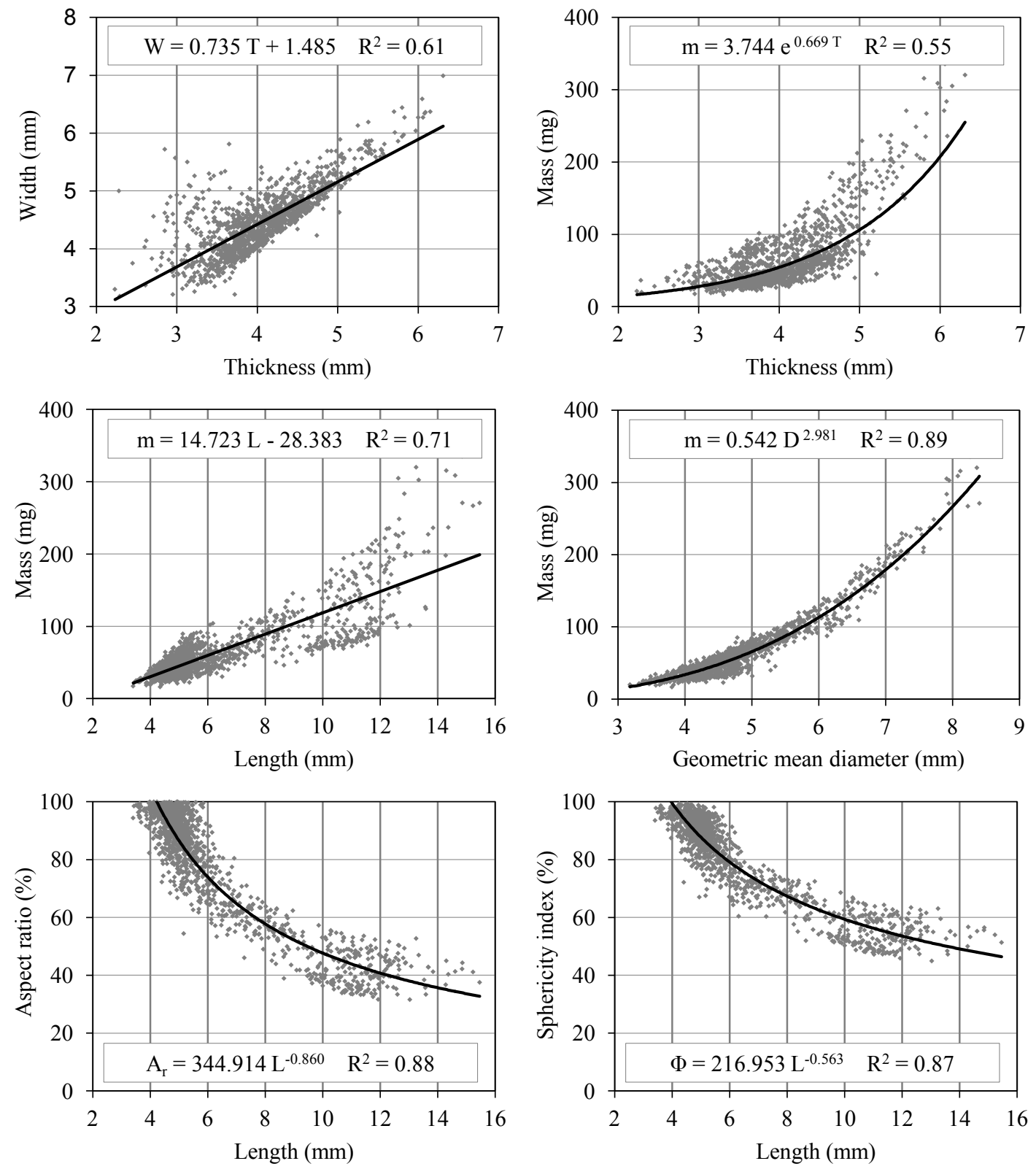

Figure 8 Relationships between the physical properties of seeds.

In further analysis, the measured parameters of dogwood seeds were pooled into a single experimental group. The relationships between the basic physical dimensions of seeds were determined by testing various regression functions. Linear, exponential and power functions (Figure 8) best fit empirical data (equations with the highest coefficient of determination). An equation with the highest coefficient of determination $\left(\mathrm{R}^{2}=0.89\right)$ was obtained for the correlation between geometric mean diameter and seed mass. An increase in geometric mean diameter from around $3.2 \mathrm{~mm}$ to around $8.4 \mathrm{~mm}$ was accompanied by a $17.12 \%$ increase in seed mass (from around $17 \mathrm{mg}$ to around $308 \mathrm{mg}$ ). Equally 
http://wjst.wu.ac.th

high coefficients of determination were noted in the relationship between seed length and seed shape, i.e. aspect ratio and sphericity index. The increase in seed length was accompanied by a decrease in aspect ratio and sphericity index which reached 33 and $46 \%$, respectively, in the largest seeds. The mass of dogwood seeds was influenced mainly by seed length and, subsequently, by seed thickness. The corresponding coefficients of determination were 0.71 and 0.55 , respectively.

Seed mass is most highly influenced by seed length and, subsequently, by seed thickness, which implies that an increase in seed length does not induce a proportional increase in the remaining seed parameters. The above can be inferred from the curves illustrating the influence of seed length on seed shape. Dogwood seeds with an estimated length of $3.5-5.5 \mathrm{~mm}$ are spherical in shape (aspect ratio and sphericity index values approximate $100 \%$ ). The shape of longer seeds resembles an ellipsoid of revolution (Figure 1), and an increase in seed length contributes to greater disproportions between seed length and the remaining parameters. For this reason, aspect ratio and sphericity index values change exponentially and are stabilized at around 33 and $46 \%$, respectively.

The presented regression equations well fit empirical data and can be effectively used to plan and perform processing operations that involve dogwood seeds.

\section{Conclusion}

An analysis of the seeds of 11 dogwood species did not reveal any species pairs characterized by significant similarities in all of the evaluated parameters. The highest number of similarities was noted in the seeds of Cornus alba, Cornus amonum and Cornus obliqua, and in the seeds of the Cornus controversa and Cornus sanguinea, whereas Cornus mas seeds were least similar to the seeds of the remaining dogwood species. The seeds of the analyzed dogwood species were arranged in the following ascending order in terms of their geometric mean diameter: Cornus macrophylla, Cornus alba, Cornus amonum, Cornus kousa, Cornus obliqua, Cornus controversa, Cornus walteri, Cornus sanguinea, Cornus florida, Cornus officinalis and Cornus mas.

The seeds of Cornus sanguinea and Cornus walteri could be separated with the use of mesh sieves with round openings; the seeds of Cornus alba, Cornus controversa, Cornus florida, Cornus kousa, Cornus mas and Cornus officinalis - with the use of mesh sieves with longitudinal openings, and the seeds of Cornus alba and Cornus obliqua - with the use of cylindrical graders. Cornus macrophylla seeds can be effectively sorted with the use of all of the above separators.

The shape of dogwood seeds is highly correlated with seed length and somewhat less correlated with seed thickness and seed width. In dogwood species producing seeds with an estimated length of 3.5 $5.5 \mathrm{~mm}$, seeds are spherical in shape, whereas in species producing longer seeds, seed shape resembles an ellipsoid of revolution.

\section{Acknowledgements}

The author would like to thank Ms. Karina Aptacy, Mr. Wojciech Kulikowski and Mr. Przemysław Damian Wiśniewski, students majoring in Agricultural and Forest Engineering at the University of Warmia and Mazury in Olsztyn, for measuring the physical properties of dogwood seeds as part of their dissertation research.

\section{References}

[1] A Marosz. Dogwoods (in Polish). Szkótkarstwo 2001; 2, 21-4.

[2] C Fan and QY Xiang. Phylogenetic relationships within Cornus (Cornaceae) based on 26S rDNA sequences. Am. J. Bot. 2001; 88, 1131-8.

[3] QY Xiang, DT Thomas, W Zhang, SR Manchester and Z Murrell. Species level phylogeny of the genus Cornus (Cornaceae) based on molecular and morphological evidence-implications for taxonomy and tertiary intercontinental migration. Taxon 2006; 55, 9-30.

[4] A Shi, S Kantartzi, M Mmbaga and P Chen. Development of ISSR PCR markers for diversity study in dogwood (Cornus spp.). Agric. Biol. J. N. Am. 2010; 1, 189-94. 
http://wjst.wu.ac.th

[5] S Celik, I Bakirci and IG Sat. Physicochemical and organoleptic properties of yogurt with cornelian cherry paste. Int. J. Food Prop. 2006; 9, 401-8.

[6] A Gasik, M Mitek and S Kalisz. Impact of the maceration process and storage conditions on the antioxidant capacity and content of some selected components in the cornelian cherry juice (in Polish). Żywność. Nauka. Technologia. Jakość. 2008; 5, 161-7.

[7] SM Bijelić, BR Gološin, JI Ninić Todorović, SB Cerović and BM Popović. Physicochemical fruit characteristics of cornelian cherry (Cornus mas L.) genotypes from Serbia. HortScience 2011; 46, 849-53.

[8] AZ Kucharska. Zwiazki aktywne owoców derenia (Cornus mas L) [Active compounds of cornelian cherry fruit (Cornus mas L.)] (in Polish). Wydawnictwo Uniwersytetu Przyrodniczego, Wrocław, 2012, p. 1-138.

[9] R Soltani, A Gorji, S Asgary, N Sarrafzadegan and M Siavash. Evaluation of the effects of Cornus mas L. fruit extract on glycemic control and insulin level in type 2 diabetic adult patients: A randomized double-blind placebo-controlled clinical trial. Evid. Based Complement. Alternat. Med. $2015 ; \mathbf{1 4 7}, 740954$.

[10] AZ Kucharska, A Szumny, A Sokół-Łętowska and K Zając. Fatty acid compositions of seed oils of cornelian cherry (Cornus mas L.). Acta Biochim. Pol. 2009; 56, 21-2.

[11] AZ Kucharska, A Sokół-Łętowska and N Piórecki. Morphological, physical \& chemical, and antioxidant profiles of polish varieties of cornelian cherry fruit (Cornus mas L.) (in Polish). Żywność. Nauka. Technologia. Jakość 2011; 3, 78-89.

[12] R Vidrih, Ž Cejic and J Hribar. Content of certain food components in flesh and stones of the cornelian cherry (Cornus mas L.) genotypes. Croat. J. Food Sci. Technol. 2012; 4, 64-70.

[13] E Falleri. Dormancy breaking in Cornus sanguinea seeds. Seed Sci. Technol. 2004; 32, 1-4.

[14] H Liu, C Qian, J Zhou, X Zhang, Q Ma and S Li. Causes and breaking of seed dormancy in flowering dogwood (Cornus florida L.). HortScience 2015; 50, 1041-4.

[15] A Załęski. Nasiennictwo leśnych drzew i krzewów iglastych [Management of coniferous forest trees and shrubs for seed production] (in Polish). Oficyna Edytorska, Wydawnictwo Świat, Warszawa, 1995 , p. 117-21.

[16] Z Kaliniewicz, A Grabowski, A Liszewski and S Fura. Analysis of correlations between selected physical attributes of Scots pine seeds. Tech. Sci. 2011; 14, 13-22.

[17] Z Kaliniewicz and A Poznański. Variability and correlation of selected physical attributes of smallleaved lime (Tilia cordata Mill.) seeds (in Polish). Sylwan 2013; 157, 39-46.

[18] NN Mohsenin. Physical Properties of Plant and Animal Materials. Gordon and Breach Science Public, New York, 1986, p. 1-891.

[19] M Rabiej. Statystyka z programem Statistica [Statisctics in Statistica software] (in Polish). Helion, Gliwice, 2012, p. 1-344.

[20] J Castro. Seed mass versus seedling performance in Scots pine: A maternally dependent trait. New Phytol. 1999; 144, 153-61.

[21] J Oleksyn, PB Reich, MG Tjoelker and W Chalupka. Biogeographic differences in shoot elongation pattern among European Scots pine populations. For. Ecol. Manag. 2001; 148, 207-20.

[22] AT Moles and M Westoby. Latitude, seed predation and seed mass. J. Biogeogr. 2003; 30, 105-28.

[23] ET Mezquida and CW Benkman. The geographic selection mosaic squirrels, crossbills and Aleppo pine. J. Evol. Biol. 2006; 18, 348-57.

[24] C Bai, B Cao, G Li and M Mao. Ecological effects on phenotypic, cytological and biochemical diversity of Cornus officinalis germplasm resources in China and USA. Biochem. Syst. Ecol. 2014; 55, 241-8.

[25] A Islamovic, M Mlaco, N Berbic, A Begic-Akagic, S Orucevic, A Bulbulusic, D Ekeberg and P Drkenda. Seasonal variation of the physical and chemical parameters of wild genotypes of cornelian cherry (Cornus mas L.). J. Int. Sci. Publ. Agric. Food 2014; 2, 466-71.

[26] F Demir and İH Kalyoncu. Some nutritional, pomological and physical properties of cornelian cherry (Cornus mas L.). J. Food Eng. 2003; 60, 335-41. 
http://wjst.wu.ac.th

[27] J Grochowicz. Maszyny do czyszczenia i sortowania nasion [Seed cleaning and sorting machines] (in Polish). Akademia Rolnicza, Lublin, 1994, p. 25-8.

[28] P Tylek. Friction and elasticity as separation properties of beech nuts (in Polish). Sylwan 2006; 5, 51-8.

[29] ML Khan. Effects of seed mass on seedling success in Artocarpus heterophyllus L., a tropical tree species of north-east India. Acta Oecol. 2004; 25, 103-10.

[30] WC Parker, TL Noland and AE Morneault. The effects of seed mass on germination, seedling emergence, and early seedling growth of eastern white pine (Pinus strobus L.). New Forests 2006; 32, 33-49.

[31] K Upadhaya, HN Pandey and PS Law. The effect of seed mass on germination, seedling survival and growth in Prunus jenkinsii Hook.f. \& Thoms. Turk. J. Bot. 2007; 31, 31-6.

[32] JR Barbour and JPF Carvaiho. Response of Rocky Mountain juniper (Juniperus scopulorum) seeds to seed conditioning and germination treatments. Seed Technol. 2009; 31, 43-54.

[33] N Norden, MI Daws, C Antoine, MA Gonzalez, NC Garwood and J Chave. The relationship between seed mass and mean time to germination for 1037 tree species across 5 tropical forests. Func. Ecol. 2009; 23, 203-10. 